\title{
Stabilising characteristics of New Zealand indigenous riparian colonising plants
}

\author{
M. Marden ${ }^{1,3}$, D. Rowan ${ }^{1}$ \& C. Phillips ${ }^{2}$ \\ ${ }^{1}$ Landcare Research Ltd, P.O. Box 445, Gisborne, New Zealand ${ }^{2}$ Landcare Research, Box 69, Lincoln 8152 , \\ New Zealand. ${ }^{3}$ Corresponding author*
}

Received 20 October 2004. Accepted in revised form 13 December 2004

Key words: indigenous riparian plants, root growth and morphology, soil and streambank reinforcement

\begin{abstract}
This paper presents selected results on the above- and below-ground growth performance of twelve indigenous woody species commonly found growing naturally in unstable riparian slope and/or bank environments throughout New Zealand. This study was needed because little information exists on the effectiveness of New Zealand's indigenous riparian plant species for slope and stream bank stabilisation. By examining the growth performance of selected riparian species during the first 5 years following establishment, we provide valuable insights into the likely strengths and limitations of individual species at maturity and, therefore, into their overall potential usefulness, singularly and/or as mixed plantings, for future riparian stabilisation projects. For all species, their root systems are typically shallow and confined to the uppermost $31 \mathrm{~cm}$ of soil. Root spread (mean maximum diameter) increased with increasing age with interspecies differences, by age 5 years, ranging from between $\sim 1$ and $2.5 \mathrm{~m}$. At age 5 years the mean root biomass, for all species combined, was $1.2 \mathrm{~kg} / \mathrm{plant}$, and averaged $23 \%$ of total plant biomass. Changes in the allocation of biomass for root and shoot growth appear to be species and age dependent. The results of this study indicate that most have above- and below-ground growth attributes well suited to colonising steep and unstable riparian slopes where shallow soil failure is prevalent and/or where stream banks are rocky with skeletal soils. All form part of the early plant succession. Once established, and in the absence of grazing, they are relatively fast growing. The effectiveness of riparian restoration programmes using indigenous species, though potentially high for low-order stream, will be limited by their relatively shallowrooted habit for bank stabilisation on larger rivers without the prior installation of structural protection works.
\end{abstract}

\section{Introduction}

Since the turn of the 20th century much of New Zealand's indigenous riparian vegetation has been cleared for pastoral use, for the development of an exotic forest industry, and for urban development associated with European settlement. In more recent years, in hill country areas, the regeneration of indigenous species has been suppressed by continual grazing, while remaining

\footnotetext{
* FAX No: + 64-6-8631346.

E-mail: mardenm@landcareresearch.co.nz.
}

stands of riparian vegetation have been further decimated largely through state-assisted landdevelopment encouragement loans or subsidies. The loss of buffering and ecosystem services provided by this riparian vegetation has led to the progressive degradation of waterways through increased sedimentation and nutrient pollution. The consequence has been a loss of in-stream habitat and inferior water quality in many streams and lakes throughout rural New Zealand (Phillips et al., 2001).

Channel widening by bank collapse is now a common occurrence along many kilometers of 
stream throughout New Zealand. The loss of primary agricultural land and physical property adjacent to eroding stream banks is very costly and the need for their protection against erosion has long been recognised (Acheson, 1968, Eyles, 1983).

An increase in awareness of the poor health of New Zealand's water bodies and a genuine willingness to redress this situation have increased the public's desire to become involved in restoring riparian areas by planting indigenous woody rather than exotic species such as willows (Salix spp.). Though the role of the latter in improving stream habitat and bank stability and in preventing erosion is well-recognised (Van Kraayenoord and Hathaway, 1986), information on the nature, and more importantly on the performance, of New Zealand's indigenous riparian species is generally descriptive, with much of our knowledge anecdotal. In the case of belowground growth performance and functionality, there are few published studies on root system architecture and biomass of individual tree species (Watson et al., 1995, 1999).

A further need to address this information gap has arisen as a result of the increased risk to many riverbank protection works posed by the introduced willow sawfly (Nematus oligospilus), which has caused widespread defoliation and mortality among New Zealand's willow trees (Cowley and Whyte, 1997). Historically, effective structural stream bank protection has been expensive to install and maintain, and as riverbank protection using only willows is no longer practical, other options are needed. This includes combining the proven capability of willows with the untested ability of native species with the view to reducing the longer-term reliance on willows. With public and government pressure to maintain and enhance the indigenous biodiversity of New Zealand, river engineers are seeking to use indigenous plants.

Increasingly, societal considerations have become an integral part of riparian stabilisation projects. These may include incorporating the aspirations of Maori (indigenous people of New Zealand) in plant selection for use in traditional medicine, as fibre for weaving, and for other uses. Other multiple goals may include increasing New Zealand's plant diversification and maximis- ing plant performance for carbon accrediting. New Zealand ratified the Kyoto Protocol (IPCC, 2000) in 1997 (New Zealand Climate Change Office, 2003), and since then the trading of carbon credits by organizations and companies at local, regional and national levels has become an integral part of the country's economy. It is important therefore, that a measure of biomass accumulation, particularly during the early years following the establishment of new plantings of indigenous species, is based on verifiable data.

In this paper we present the results of a trial in which we quantify the, above- and belowground growth performance of twelve, 1- to 5 -year-old, indigenous plant species. These species are part of the early plant succession frequently found growing naturally in unstable riparian slope and/or bank environments throughout New Zealand. Despite little documented information on appropriate plant spacing or of an understanding of why certain species appear better adapted to stabilise different riparian environs, e.g., floodplain stream banks, colluvial slopes, landslide scars, many of the trialled species are currently being planted for streamside restoration. By examining their growth performance we aimed to provide valuable insights into the strengths and limitations of individual species and their overall potential usefulness, singularly and/or as mixed plantings, for riparian stabilisation. This trial is the first of its kind to attempt to provide such data in New Zealand.

\section{Methods}

It was not considered practical or environmentally acceptable to source plants for destructive sampling, directly from their natural environment. Because of the restrictions planter bags have on root development of containerised plants, it was imperative we secured a source of bare-rooted material at least for plants older than 2 years. We used 2-year-old containerised plants and established a trial site from which plants could be on grown and periodically extracted. To minimise the influence of site variability on growth and to emulate riparian conditions, we chose a streamside location with uniform soils, slope and aspect. 
Table 1. Indigenous riparian species trialled and number of sample trees extracted for each species and year of the trial

\begin{tabular}{|c|c|c|c|c|c|c|c|}
\hline \multirow[t]{2}{*}{ Common name } & \multirow[t]{2}{*}{ Botanical name } & \multicolumn{6}{|c|}{ Number of plants extracted/species/year } \\
\hline & & 1 & 2 & 3 & 4 & 5 & Species total \\
\hline Karamu & Coprosma robusta & 10 & 10 & 7 & 8 & 10 & 45 \\
\hline Ribbonwood & Plagianthus regius & 10 & 10 & 10 & 10 & 10 & 50 \\
\hline Kowhai & Sophora tetraptera & 10 & 8 & 8 & 8 & 10 & 44 \\
\hline Lemonwood & Pittosporum eugenoides & 10 & 10 & 10 & 10 & 10 & 50 \\
\hline Kohuhu & Pittosporum tenuifolium & 10 & 10 & 10 & 9 & 10 & 49 \\
\hline Lacebark & Hoheria populnea & 10 & 10 & 10 & 10 & 8 & 48 \\
\hline Mapou & Myrsine australis & 10 & 10 & 10 & 10 & 10 & 50 \\
\hline Fivefinger & Pseudopanax arboreus & 10 & 10 & 10 & 8 & 8 & 46 \\
\hline Cabbage tree & Cordyline australis & 10 & 10 & 10 & 10 & 10 & 50 \\
\hline Rewarewa & Knightia excelsa & 10 & 10 & 10 & 10 & 9 & 49 \\
\hline Manuka & Leptospermum scoparium & 10 & 10 & 5 & 0 & 5 & 30 \\
\hline Tutu & Coriaria arborea & 10 & 10 & 10 & 8 & 5 & 43 \\
\hline Annual totals & & 120 & 118 & 110 & 101 & 105 & 554 \\
\hline
\end{tabular}

\section{Site details}

The trial site was located on a low-lying, evensurfaced alluvial terrace adjacent to the Taraheru River, in Gisborne City, North Island, New Zealand. The soil is free draining, Te Hapara Typic Sandy Brown Soil (Hewitt, 1998) and requires irrigation in summer. The site $(50 \mathrm{~m}$ by $20 \mathrm{~m})$ was tilled and weed mat was laid down before planting in 1999. The site was subdivided into three blocks. Two-year-old containerised plants were sourced from a local plant nursery and all three blocks were planted in a day. Within each block, plants were arranged so that individuals of the same species were not adjacent. Blocks-1 and -2 (plants to be extracted 1 and 2 years after planting, i.e. at age 3 and 4, respectively) were planted at $1-\mathrm{m}$ spacing, and block-3 (plants to be extracted 3 years after planting, i.e. at age 5) at 1.5-2.0$\mathrm{m}$ spacing. Plants were irrigated for the first 3 months after planting.

\section{Species selection}

The species (Allan Herbarium, 2000) chosen (Table 1) are those to appear as part of the natural reversion process on retired pastoral land and on areas of bare ground (mostly landslide scars), or are regarded as suitable for direct planting to restore and stabilise riparian zones.

\section{Biomass and morphology}

Plant age was established from the date each species was pricked-out into containers (zero years). For data on 1- and 2-year-old plants, we destructively partitioned the containerised plants. Data for plants 3-5 years old are for bare-rooted plants excavated from the trial site. Using an air lance at $240 \mathrm{kPa}$, soil surrounding the root systems was removed allowing them to be extracted undamaged and a high percentage of the total root mass to be recovered. We aimed for a sample size of ten plants/species/year. Frost, insect attack and wind-throw accounted for the shortfall in sample size for some of the species, e.g., manuka in year 4 . Over the duration of this trial, 554 individual plants were destructively sampled (Table 1).

Above-ground growth parameters measured included height, canopy spread, root collar diameter and diameter at breast height $(\mathrm{DBH})$ (where applicable). Below-ground growth measurements included maximum root depth and lateral root spread. The latter, together with canopy spread, was taken as the average of the maximum diameters measured in two directions. The root system of each plant was photographed before being partitioned into its biomass components. In addition, the above- and below-ground form of a 5-year-old specimen of each species was sketched in detail. 
Above-ground biomass was measured by separating the foliage, branches and stem. Below-ground components were partitioned into root bole, tap, lateral and sinker roots. Roots were further partitioned into diameter size classes ( $<1 \mathrm{~mm}$ (fibrous), 1-2, 2-5, 5-10 and 10$20 \mathrm{~mm}$ ) (Watson and O'Loughlin, 1990), and the total length of roots in each diameter size class (excluding fibrous roots) was measured. Relative to the root bole, a measure of the distribution of root biomass and root length (of roots $>1 \mathrm{~mm}$ ), by diameter size class, was recorded for each $50-\mathrm{cm}$ radius by $50-\mathrm{cm}$ deep concentric disc (similar to growth rings) to the maximum extent of root growth. Each of the above- and below-ground biomass components was oven-dried at $80{ }^{\circ} \mathrm{C}$ for $24 \mathrm{~h}$ then weighed to the nearest $0.1 \mathrm{~g}$.

Root systems and types are described as (Phillips and Watson, 1994):

Tap-rooted. The seedling radicle persists and grows into a single or branched massive root (taproot), more or less vertical; it may give rise to planes of lateral roots.

Plate. A shallow spreading root system with abundant surface roots, no taproot.

Heart-rooted. A compact system with many obliquely or vertically descending roots (heart roots) rising from or near the root bole and generally replacing the taproot.

Lateral roots. Long and radially spreading from the taproot, or from the root bole, possibly in two or more plates or strata.

Sinker roots. Roots descending more or less vertically from the main laterals at varying distances from the root bole and to depths up to or exceeding that of the taproot.

\section{Statistical analyses}

All analyses were carried out in the statistical package GenStat (2002) using the procedure for unbalanced analysis of variance (procedure AUNBALANCED). Analysis on the raw data revealed the residuals (assessed visually) showed significant non-normality (skewed to the right) and an increasing variance with increasing fitted values (heteroscedasticity). All data were $\log _{10}$-transformed to impose normality on the residuals. Throughout this paper, means (back transformed from the $\log _{10}$ scale) are presented \pm 1 standard error.

\section{Results}

\section{Root system types}

Of the trialled species, cabbage tree was the only one to develop a taproot system consisting of a central, frequently branched, tuberous root/rhizome. The remaining species all developed heartrooted systems. Of note were the lateral roots of ribbonwood, lemonwood and kohuhu, which at an early age developed a few long thin laterals (mean root spread $>2 \mathrm{~m}$ at age 5). The distribution of their leading lateral roots was highly asymmetric with large areas of soil totally devoid of any roots. Multiple branching was most common at the extremities. Typically, multiple and large-diameter roots developed early and descended obliquely from the base of the root bole. Mapou and kowhai clearly developed sinker roots. These became apparent in year four; they developed between 0.5 and $1 \mathrm{~m}$ from the stump and each descended to a depth of $\sim 0.15-0.20 \mathrm{~m}$ by age 5 years. Mapou and rewarewa root systems were compact (mean root spread $<1 \mathrm{~m}$ at age 5 years), highly branched close to the root bole, and had a matted appearance, with the dense cluster of fine roots proving difficult to tease apart.

\section{Root depth}

For all species combined there was a significant increase in root depth between years one and five (Figure 1) with inter-species differences being apparent at an early age (Figure 2). Mean root depth for all species combined, at age 5 years, was $0.3 \mathrm{~m}$ (Figure 1). The deepest rooted cabbage tree reached a mean depth of $\sim 0.4 \mathrm{~m}$, while mapou had the shallowest root system at $\sim 0.2 \mathrm{~m}$. At age 5 years the root network was largely confined to the uppermost $31 \mathrm{~cm}$ of organic-rich topsoil.

\section{Root spread}

For all species combined there was a significant increase in root spread between years one and five (Figure 3). Constriction of the roots in planter bags explains the lack of variation in root spread in years one and two. Lemonwood 


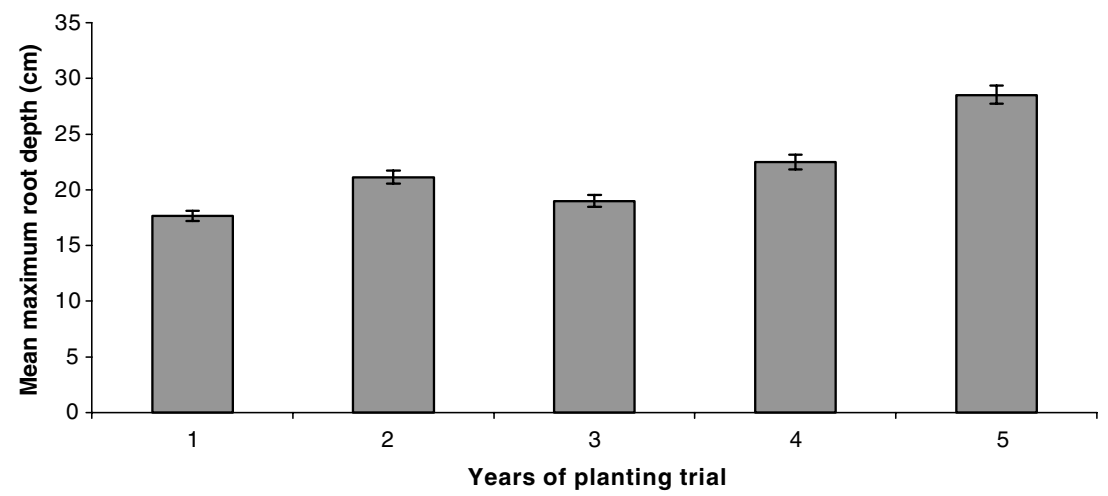

Figure 1. Mean maximum root depth for all 12 riparian species combined, over the 5-year trial period (difference between means is highly significant $F_{4,491}=43.28, P<0.001$ ). Error bars are \pm 1 SE. See Table 1 for the number of plants extracted.

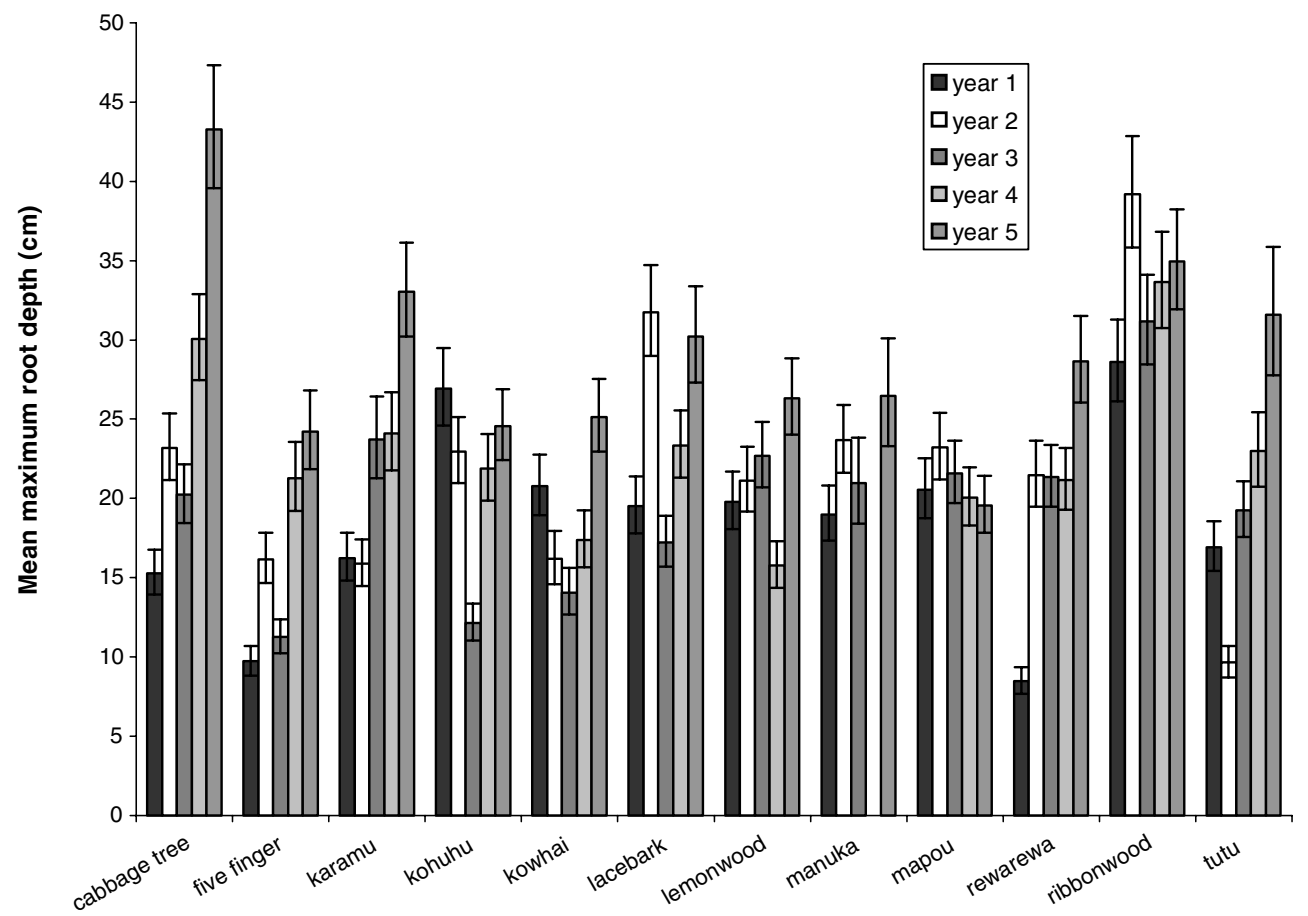

Figure 2. Changes in mean maximum root depth for individual species during their first 5 years of growth (interaction between species and year is highly significant $F_{43,491}=7.07, P<0.001$ ). Error bars are \pm 1 SE. See Table 1 for the number of plants extracted.

achieved the greatest mean root spread at $\sim 3 \mathrm{~m}$ (Figure 4). In contrast, the very compact root systems of mapou and rewarewa barely attained a mean spread of $1 \mathrm{~m}$. For all species trialled, the lateral root spread for plants 3-5 years old generally exceeded crown width. In the trial plot and by year four, the roots of adjacent plants at $2-\mathrm{m}$ spacing were intertwined. The root systems of individual kowhai and tutu extended to a maximum distance twice the diameter of their respective canopy widths.

\section{Root biomass}

As for root depth and spread, the relative consistency of root biomass in years one and two for 


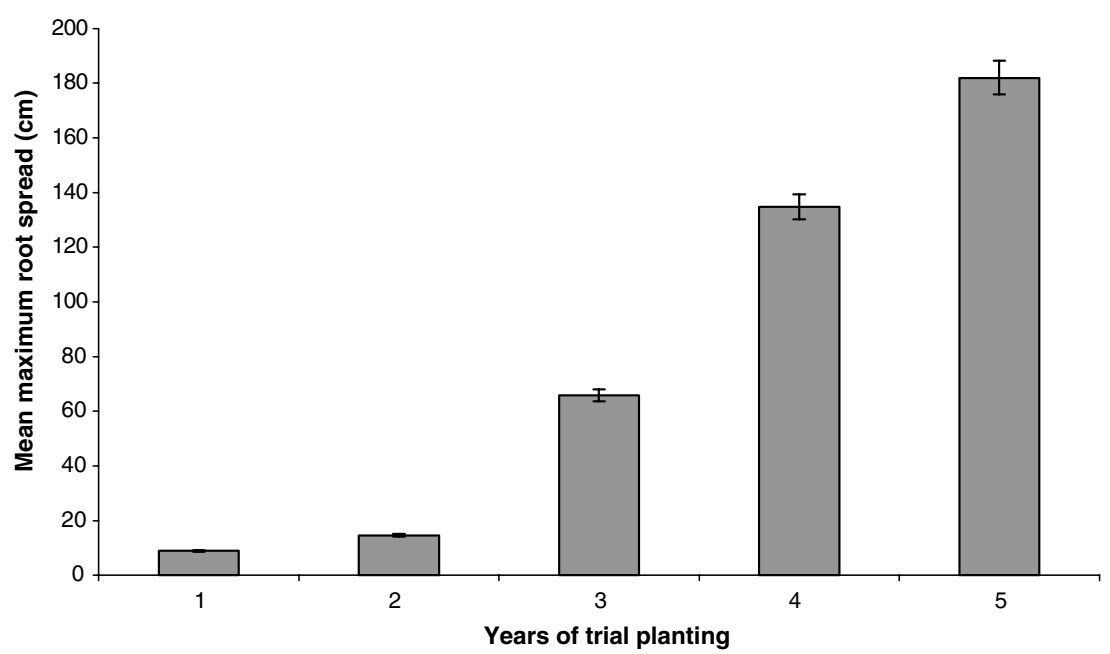

Figure 3. Mean maximum root spread for all 12 riparian species combined, over the 5-year trial period (difference between means is highly significant $\left.F_{4,493}=1584.8, P<0.001\right)$. Error bars are $\pm 1 \mathrm{SE}$. See Table 1 for the number of plants extracted.

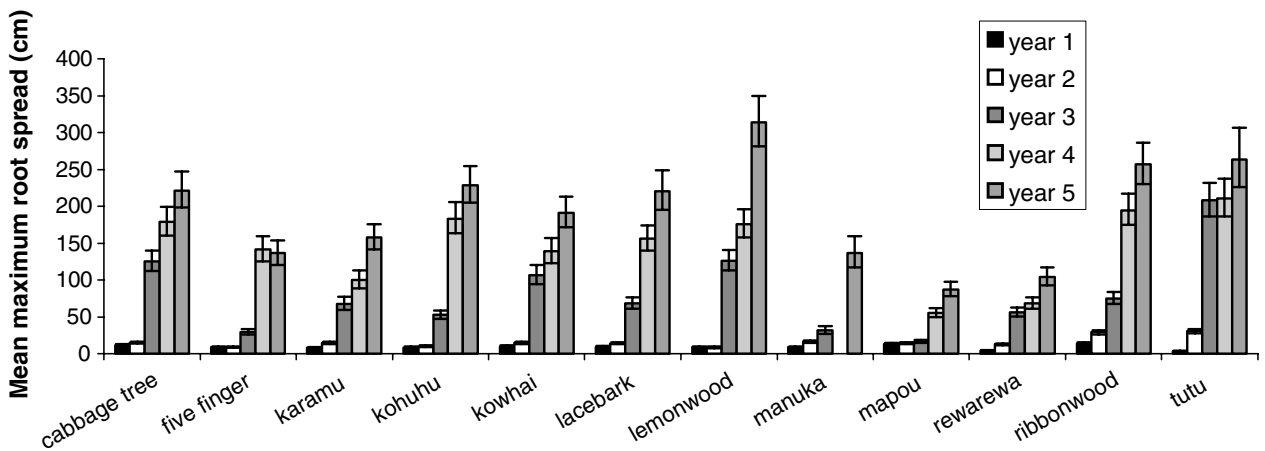

Figure 4. Changes in mean maximum root spread for individual species during their first 5 years of growth (interaction between species and year is highly significant $F_{43,493}=12.64, P<0.001$ ). Error bars are \pm 1 SE. See Table 1 for the number of plants extracted.

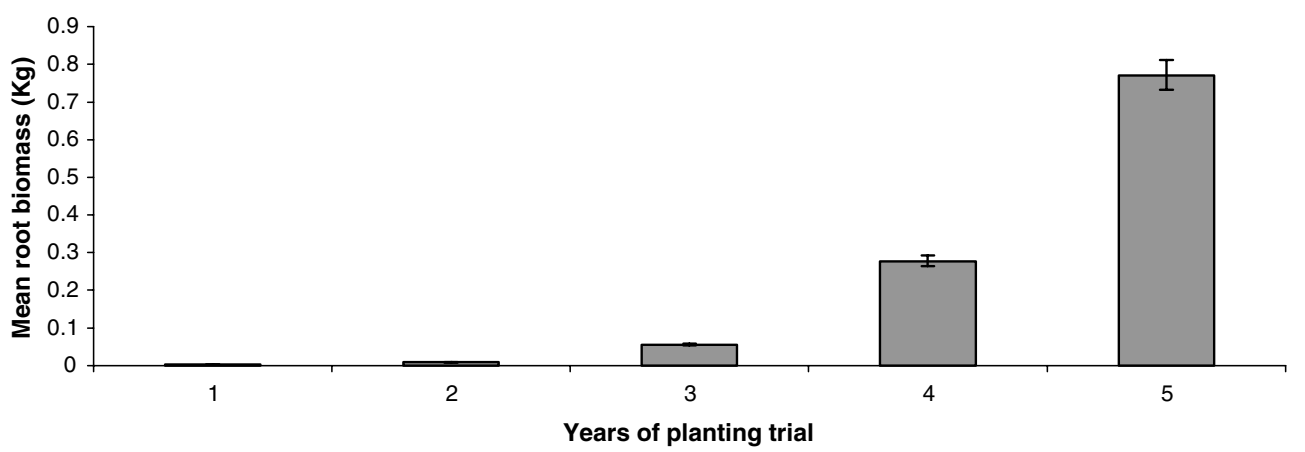

Figure 5. Mean root biomass for all 12 riparian species combined, over the 5-year trial period (difference between means is highly significant $\left.F_{4,494}=2126.8, P<0.001\right)$. Error bars are \pm 1 SE. See Table 1 for the number of plants extracted. 
all species combined (Figure 5) was due to the restrictive size of the planting bag. Between years four and five the mean root biomass, for all species combined, more than doubled to $1.2 \mathrm{~kg} /$ plant, and averaged $23 \%$ of total plant biomass. At 5 years old, kowhai had the highest percentage of root biomass at $29 \%$, and manuka and cabbage tree the least, at $19 \%$.

All twelve species showed a decrease in fine roots $<1 \mathrm{~mm}$, and a corresponding increase in larger diameter roots with increasing age. The fine root fraction of the tap-rooted cabbage tree was consistently lower, at $<20 \%$ of total root weight, than for the remaining species in each year of the trial. Irrespective of age, the biomass of the root bole (stump) remained relatively constant, at $\sim 25 \%$ of total root weight, for all but three species. The small and largely fibrous root systems of manuka and mapou each maintained a comparatively small root bole for all 5 years of growth, comprising $\sim 10 \%$ of total root weight. In contrast, the cabbage tree showed significant growth in its taproot from nothing in year one to $\sim 80 \%$ of total root weight in year five.

\section{Root/shoot ratio}

Changes in the allocation of biomass for root and shoot growth appear to be species and age dependent. For example, cabbage tree initially invested $\sim 55 \%$ of total plant biomass in rhizome growth but by year five this had declined to $\sim 20 \%$ (Figure 6). Lacebark showed a similar trend. In year one, the initial high investment in root biomass for some species is apparent and the result of root binding and anchorage strategies. In contrast, fivefinger, kohuhu, rewarewa, ribbonwood and lemonwood showed a steady, but small, annual increment in root biomass relative to shoot biomass. For all species combined, mean root biomass averaged $37 \%$ in year one and remained relatively constant between years two and five, at not less than $30 \%$ of total plant biomass (Figure 7). For individual species, and over the 5-year duration of the trial, kowhai, lacebark, manuka, mapou and ribbonwood invested significantly more of its total plant biomass as root biomass $(\sim 40 \%)$ compared with $\sim 30 \%$ for the remainder of species trialled (Figure 8).

\section{Discussion}

The commonly held belief that New Zealand's indigenous plant species are too slow growing, though true when young, is not the case once plants have become established, with the majority showing exceedingly fast biomass growth within 3 years of planting-out. However, as is common with plants less than 2 years old, factors such as wrenching, root training and planter bag constriction have contributed to the apparent similar rate of growth exhibited during this period (Marden and Phillips, 2002). In years three and four, interspecies differences in overall growth became apparent, with lemonwood, ribbonwood, cabbage tree, karamu, lacebark and tutu the better performers (Marden and Phillips, 2003, 2004), and this trend continued into the last year of the trial.

Site-factors may have contributed to some of the inter-species differences in growth performance. For example, manuka showed significantly slower growth in the fertile soils at the trial site than has previously been measured for similar aged plants growing on less fertile sites more typical of their natural occurrence (Watson et al., 1995). In addition, the openness of the trial site may have affected the early growth performance of the more shade tolerant species including mapou, lemonwood and fivefinger; though once established all proved to be sufficiently hardy to tolerate full sun.

Most are colonising species adapted to harsh growing conditions on steep slopes with skeletal soils deficient in nutrient, and are considered as a nurse crop for emerging shrubby hardwoods. Adaptations include the presence of nitrogen fixing nodules on roots of 4-year-old tutu and kowhai (Marden and Phillips, 2003) and/or roots with a high tensile strength, e.g., kowhai, (Watson and Marden, 2004) for clinging to barren, dry, steep rocky cliffs. Other species are equally at home on alluvial floodplains and have adaptations to cope with periodic flooding and siltation by producing adventitious roots. Cabbage tree, for example, is able to produce adventitious roots from its stem should the tree topple over or break, while tutu is capable of layering should branches break and become buried. Mapou was observed to sprout suckers from lateral surface roots. Foweraker (1929) also highlighted the 


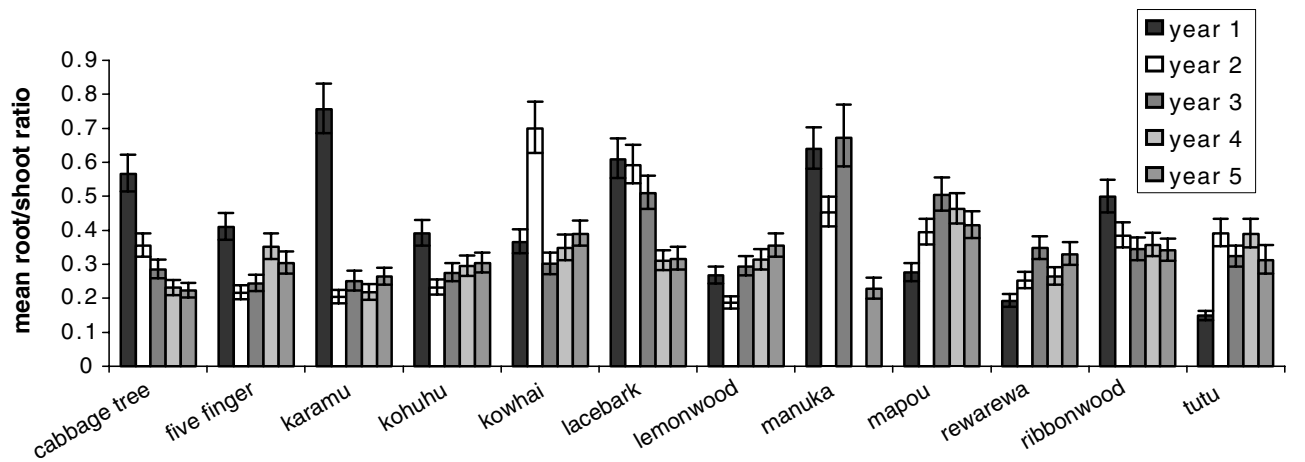

Figure 6. Changes in mean root/shoot ratio for individual species during their first 5 years of growth (interaction between species and year is highly significant $F_{43,494}=11.22, P<0.001$ ). Error bars are \pm 1 SE. See Table 1 for the number of plants extracted.

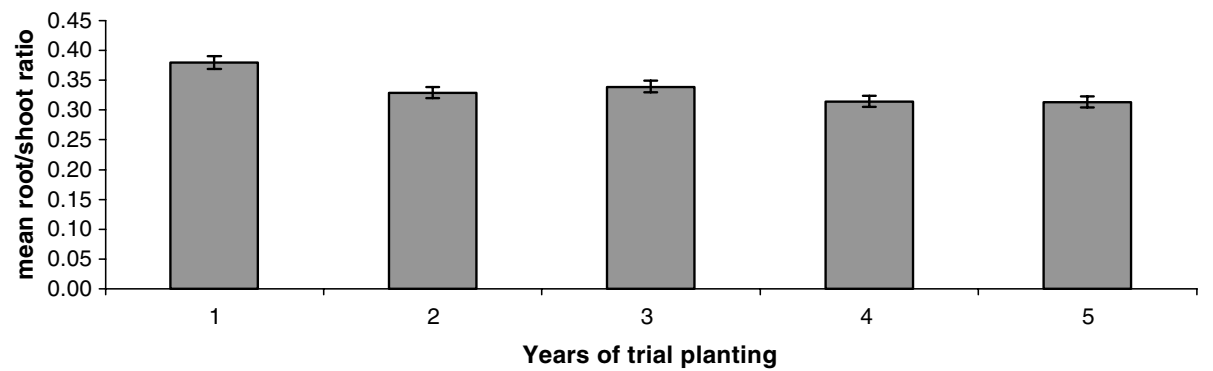

Figure 7. Mean annual root/shoot ratio for all 12 riparian species combined, over the 5 -year trial period (difference between means is highly significant $F_{4,494}=7.27, P<0.001$ ). Error bars are \pm 1 SE. See Table 1 for the number of plants extracted.

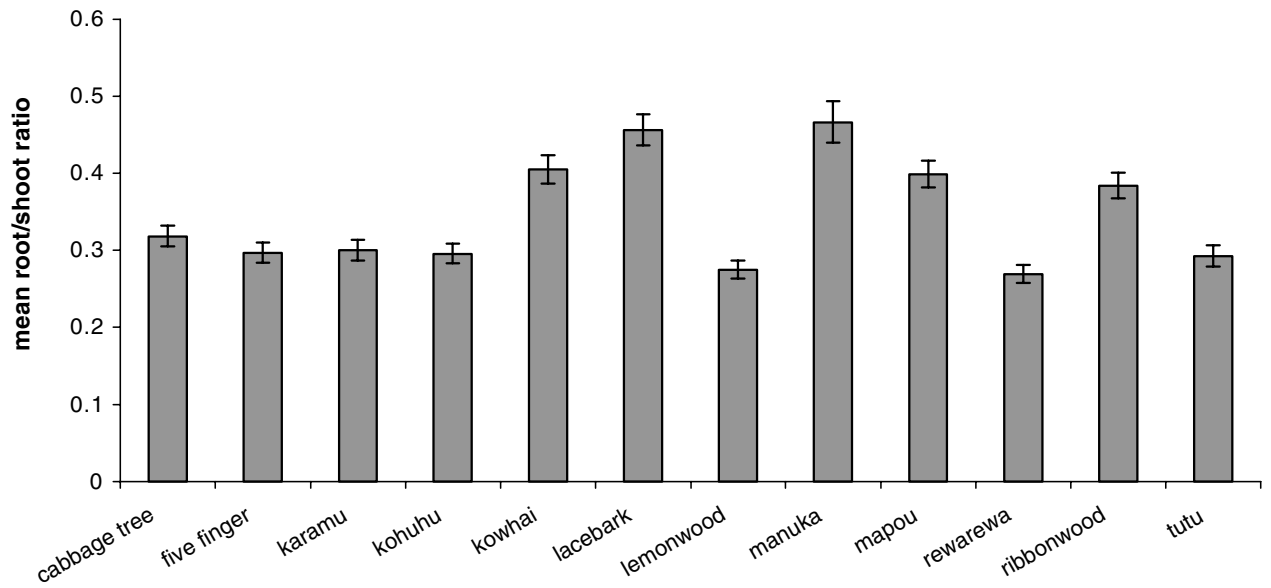

Figure 8. Mean root/shoot ratio for individual species, averaged over the 5 -year trial period (difference between means is highly significant $\left.F_{11,494}=19.57, P<0.001\right)$. Error bars are \pm 1 SE. See Table 1 for the number of plants extracted.

interesting ability of alluvial communities of some of New Zealand's oldest podocarps to produce a new root system after inundation with river silt.
Potential limitations include susceptibility to frost (e.g., tutu), scale insects (e.g., manuka), and leaf rust (e.g., rewarewa and karamu) (Marden and Phillips, 2003). Some are short lived (e.g., 
tutu) and together with shade intolerant species will become suppressed and replaced by others. The toxicity of tutu foliage to grazing domestic stock and the potential of contamination of honey produced at the time tutu is in flower, will further limit its application for riparian restoration particularly in urban and unfenced rural settings. Toppling of cabbage trees, whether they are found in isolation or as communities, has previously been documented by Czernin (2002), and was a common occurrence in the latter years of the current study. The prevalence of toppling at our trial site is attributed to a combination of: (a) the structural homogeneity of the alluvial soil where lateral roots tended to pull out of the soil rather than break; (b) a rapid increase in shoot biomass to $80 \%$ of total biomass by age 5 years; and (c) tall tree height $(\sim 3 \mathrm{~m})$, by age 5 years.

The most efficient slope stabilisation results when root development occurs at different depths in the soil profile (Schiechtl and Stern, 1994). This was observed for cabbage tree in this study and also documented by Czernin (2002). However, our study, in common with other local (Watson et al., 1995, 1999) and international (Abernethy and Rutherfurd, 2001; Easson and Yarbrough, 2002) studies on plant root distribution, shows that for most of the riparian species studied here, roots are concentrated only in the upper soil profile. The major vertically and obliquely inclined roots for most of the trialled species were observed to change direction abruptly and strike horizontally at a relatively shallow depth. There was no consistency in the depth at which this occurred, and this may be an adaptation typical of early colonising species. Results also indicate that with increasing depth and distance from the stem there is a rapid decline in roots, that there are interspecies differences in root distribution, and that each species allocates differing proportions of their total biomass to roots at different stages of growth.

Interspecies differences in root distribution has implications for the planting densities required to provide full, near-surface root occupancy of the soil and/or to maximise the root density to the depth requirement at specific sites. The tap-rooted cabbage tree will likely provide a higher level of reinforcement directly under the stand and to a greater depth than heart-rooted species, but the reinforcement quickly tapers off laterally as root density declines away from the stand edge. In contrast, heart-rooted species will likely provide a higher level of near surface reinforcement and to a greater distance from the stem, but reinforcement will rapidly decline at a relatively shallow depth.

Previous research on root depth of older aged riparian species, for example, manuka, shows that the root system of mature trees (13-50 years old) penetrated to a depth of $0.5 \mathrm{~m}$ on stony soils and $0.8 \mathrm{~m}$ on sandy soils (Watson and O'Loughlin, 1985), and those of another colonising and closely related species of manuka, kanuka (Kunzia ericoides), at between 6 and 32 years old reached a maximum depth of between 1.5 and $2.2 \mathrm{~m}$. The latter study concluded that root depth was correlated not to tree age but rather to the stoniness and depth of slope colluvium (Watson et al., 1995). In a detailed investigation of cabbage trees, the root depth of 25 -year-old trees growing in alluvial gravel was estimated to be $\sim 2 \mathrm{~m}$ (Czernin, 2002). These studies, together with the few published reports on the root depth of some of New Zealand's tallest podocarp forest species (Cameron, 1963), indicate the rooting depth for most of New Zealand's indigenous species rarely exceeded $2 \mathrm{~m}$. The comparatively shallow rooting depth of New Zealand indigenous riparian species implies most will have a physical limitation to their ability to contribute to deep soil reinforcement.

The time required to achieve appreciable growth for many of these riparian shrub and tree species will vary greatly and depend largely on growth environment. With the exception of the higher altitudes, many of New Zealand's riparian species will achieve appreciable growth 5 years after establishment, but it may require 710 years before an effective cover is obtained.

\section{Implications for riparian restoration and management}

A significant improvement in riparian slope and bank stability is anticipated for the smaller streams more typical of unmodified, upland stream reaches where current channel form, slope characteristics and hydraulic conditions 
are better representative of what existed before forest clearance and where the performance of riparian vegetation has proven effective. For these streams, it is not the physical limitations of root system depth, spread and density of individual riparian species to provide effective soil reinforcement that determines the key to successful slope and bank stabilisation but rather the density of plantings and the species mix present. Treatment options that promote the quickest canopy closure and root development at all levels of the soil profile are likely to be the most effective in promoting site stability (Phillips et al., 2001). Where a seed source already exists and if animal stock could be excluded from riparian areas, many would regenerate naturally and at little cost. Excessive vegetative growth may, however, encroach on these channels, and without proper management may create drainage problems by clogging the stream.

As a consequence of their shallow-rooted habit, however, many of New Zealand's indigenous plants will have limited effectiveness in floodplain reaches of higher order streams modified by the building of stopbanks (levees) and where channel hydraulic conditions are likely to undercut stream banks to a very steep and unstable slope $\sim 2 \mathrm{~m}$ high. If the potential for bed degradation exists, additional protection in the form of structural materials will be required along the toe of the bank and to some depth below the normal streambed. Similarly, bank materials such as alluvium are prone to undermining, thus riparian plantings must be protected by structural means (e.g., gabion baskets, rip rap, etc.) and/or by bank reshaping until growth is sufficient to achieve effective bank stability.

The limitations of root depth aside, New Zealand's indigenous riparian vegetation is sufficiently diverse to meet most of the requirements for slope and bank restoration, particularly of the lower order streams. The selection of suitable plant materials must take into account both the degree of overbank inundation contemplated and the ability of plant materials to provide year-round protection, have the capacity to become well-established under adverse soil conditions, be long lived, develop a root system that will withstand the drag of stream flow on the above ground portion, have multistem and branch characteristics with many stems emerging from the boundary surface, have tough, resilient stems and branches, and require minimum maintenance.

Where stability is required to a known depth, such as to a potential failure plane that lies within the rooting depth of plants being considered to restore stability, the species selection must include those with root systems capable of reaching the specified depth. Failure to meet this goal will undoubtedly be the result of insufficient roots crossing the failure plane as it is below the vertical limit of root growth of the species selected. For many restoration sites the strategy should be to select a mix of species with different rooting habit. To appreciate fully the potential use of indigenous vegetation for the stabilisation of riparian slopes and streambanks in New Zealand, further studies are needed for other riparian plant species that may better meet the slope and bank stability requirements for drainage systems in different soil types, geology and with differing hydraulic characteristics.

\section{Acknowledgements}

We acknowledge the support of the Tairawhiti Polytechnic Rural Studies Unit, Gisborne, on whose land the riparian plant trial was located. We thank Alex Watson for reviewing a draft of this paper. Anne Austin is thanked for editing the final version. Statistical analyses were provided by Guy Forester (biometrician), Landcare Research, Lincoln. The Foundation of Research Science and Technology, New Zealand, provided funding under Contract No. COX 0305.

\section{References}

Abernethy B and Rutherfurd I D 2001 The distribution and strength of riparian tree roots in relation to riverbank reinforcement. Hydrol. Process. 15, 63-79.

Acheson A R 1968 River control and drainage in New Zealand. Ministry of Works, New Zealand 296 pp.

Allan Herbarium 2000 New Zealand Plant Names Database, Landcare Research, New Zealand. Available http://nzflora.landcareresearch.co.nz (Accessed 22 November 2004).

Cameron R J 1963 A study of the rooting habits of rimu and tawa in pumice soils. N. Z. J. For. 8, 771-785. 
Cowley J M and Whyte C F 1997 Impact assessment for sawfly on Willow, Nematus oligospilus Förster (Hymenoptera: Tenthredinidae). New Zealand Plant Protection Centre, Lynfield, Auckland. Internal Ministry of Agriculture Report. 20 pp.

Czernin A 2002 Above-ground and below-ground characteristics of the New Zealand cabbage tree (Cordyline australis) with particular reference to the root system morphology and root strength. MSc thesis. University of Agricultural Sciences, Vienna $183 \mathrm{pp}$.

Easson G and Yarbrough L D 2002 The effects of riparian vegetation on bank stability. Environ. Eng. Geosci. 8, 247260

Eyles G O 1983 The distribution and severity of present soil erosion in New Zealand. N. Z. Geog. 39, 12-28.

Foweraker C E, 1929 The podocarp rain forests of Westland, New Zealand. Kahikatea and Totara forests, and their relationships to silting. Te Kura Ngahere. A forestry journal issued by the Forestry Club of the Canterbury College School, Christchurch, New Zealand.

Hewitt A E 1998 New Zealand Soil Classification. 2nd edLandcare Research Science Series No. 1Manaaki Whenua Press, Lincoln, New Zealand.

IPCC, 2000: Land Use, Land-Use Change, and Forestry. A Special report of the IPCC [Watson R T, I R Noble B Bolin N H Ravindranth D J Verardo and D J Dokken, (Eds.)]. Cambridge University Press, Cambridge, UK.

Marden M and Phillips C J 2002 How do native riparian plants grow? Conservation Quorum, 14-15.

Marden M and Phillips C J 2003 Stream bank planting trials. Conservation Quorum, 12-13.

Marden M and Phillips C J 2004 Stream bank planting trialsthe final chapter. Conservation Quorum, 7-8.
New Zealand Climate Change Office 2003 Climate change. National Inventory Report for New Zealand. Greenhouse Gas Inventory, 1990-2001. Ministry for the Environment, Wellington. $86 \mathrm{pp}$.

Phillips C J and Watson A J 1994 Structural tree root research in New Zealand, a review. Landcare Research Science Series 7. Manaaki Whenua Press, Lincoln

Phillips C J, Marden M, Rowan D and Ekanayake J C 2001 Stabilising characteristics of native riparian vegetation in New Zealand. In Proc. 3rd Australian Stream Management Conference, Brisbane August 2001, 507-512.

Schiechtl H M and Stern R 1994 Handbuch für naturnahen Wasserbau, Eine Anleitung für ingenieurbiologische Bauweisen. Österreichischer Agrarverlag, Wien

Kraayenoord C W S Van and Hathaway R L 1986 Plant materials handbook for soil: conservation, Vol. 2, Introduced Plants. 229

Watson A J and O'Loughlin C L 1985 Morphology, strength, and biomass of manuka roots and their influence on slope stability. N Z J. For. Sci. 15, 337-348.

Watson A J and O'Loughlin C L 1990 Structural root morphology and biomass of three age classes of Pinus radiata. N Z J. For. Sci. 20, 97-110.

Watson A J, Marden M and Rowan D 1995 Tree species performance and slope stability. In Vegetation and Slopes. Ed. D H Barker. pp. 161-171. Thomas Telford Press, London.

Watson A J, Phillips C J and Marden M 1999 Root strength, growth, and rates of decay: root reinforcement changes of two tree species and their contribution to slope stability. Plant Soil 217, 39-47.

Watson A J and Marden M 2004 Live root wood tensile strengths of some common New Zealand indigenuous and plantation species. N Z J. For. Sci. 34(3), 344-353. 